\title{
Further evidence of a fall in blood lead levels in Wales
}

\author{
PETER ELWOOD ${ }^{1}$ AND COLIN TOOTHILL ${ }^{2}$ \\ From the MRC Epidemiology Unit, ${ }^{1} 4$ Richmond Road, Cardiff and the Supra-Regional Assay Service Lead \\ Laboratory, ${ }^{2}$ Leeds
}

SUMMARY Random samples of residents in North Wales, some of whom had been seen in 1976 and others in 1981, were seen again in 1984. Blood lead estimations indicated that there had been a fall of about $5 \%$ per year. This is similar to the fall we estimated from two previous studies in Wales and is comparable to changes described in the USA and New Zealand.

There is considerable interest in changes over time in blood lead levels. In the USA, a fall during 1976-80 has been attributed in total to a reduction of lead in gasoline. ${ }^{1}$ In view of the proposed reduction of lead in petrol in the UK by 1986 , it is important to seek evidence on changes in blood lead levels in order to facilitate the interpretation of any further changes which may occur following the introduction of low lead petrol.

In 1983 we published evidence from two studies ${ }^{2}$ which suggested that blood lead levels had fallen substantially in Wales over the previous ten years. One study was based on the mean levels in ten population surveys, the other involved a comparison of lead levels in blood samples taken in 1969 and stored at low temperature and in fresh samples taken from the same subjects in 1982. These suggested a fall in blood lead levels of about 3 to $4 \%$ per year. We now present further evidence which suggests that the fall is continuing.

\section{Method}

In 1976 we conducted surveys of random samples of male and female subjects in two old lead mining areas in Powys in Mid Wales and in Clwyd, North Wales, together with two "control" areas in Clwyd. In 1981 a further survey was conducted in one of these two lead mining areas based on a representative sample of female residents and residents in a "control" village about $30 \mathrm{~km}$ away. ${ }^{5}$ Some samples of whole blood taken in this survey were put into deep freeze.

In 1984 we returned to the areas surveyed previously, at about the same time of the year as the original surveys. Subjects who had not moved out of the area in which they had been seen originally were asked for another sample of venous blood. Lead was estimated by atomic absorption spectrophotometry using the same methods and the same instruments as in the original survey.

\section{Results}

The table shows the results. In every area there has been a fall in mean blood lead. Within the areas fo $\$$ which data are available for 1976 and 1984, th요을 changes overall represent a fall of $6.5 \mathrm{SE} 0.53 \mu \mathrm{g} / \mathrm{df}$ $(\mathrm{p}<0.001)$. The overall change in the two areas surveyed in 1981 and in 1984 is 1.9 SE $0.34 \mu \mathrm{g} / \mathrm{dP}$ Both these changes approximate to around $5 \%$ peer. year.

As a check on laboratory drift 47 samples which had been assayed in 1981 and then stored in deep freeze were re-assayed in 1984 . The mean of the

Mean blood lead levels ( $\mu$ g/dl) in population samples seen in various areas in North Wales, on two occasions-either 1976 and 1984 or 1981 and 1984

\begin{tabular}{|c|c|c|c|c|c|c|}
\hline \multirow[b]{2}{*}{ Area } & \multicolumn{2}{|c|}{$\begin{array}{l}\text { Subjects seen at } \\
\text { both times }\end{array}$} & \multicolumn{3}{|c|}{ Mean blood lead level (SD) in: } & \multirow{2}{*}{$\begin{array}{l}\% \text { Fall } \\
\text { by } 1984\end{array}$} \\
\hline & No. & Mean age & 1976 & 1981 & 1984 & \\
\hline Greenfield & 13 & $45 \cdot 8$ & $\begin{array}{c}16.7 \\
(5.9)\end{array}$ & - & $\begin{array}{c}11 \cdot 2 \\
(4 \cdot 1)\end{array}$ & 33 \\
\hline Ruthin & 19 & $58 \cdot 4$ & $\begin{array}{c}17.9 \\
(7 \cdot 0)\end{array}$ & - & $\begin{array}{c}12.6 \\
(5 \cdot 0)\end{array}$ & 30 \\
\hline Y Fan & 38 & $57 \cdot 6$ & $\begin{array}{c}18.7 \\
(6.9)\end{array}$ & - & $\begin{array}{c}10 \cdot 2 \\
(3.2)\end{array}$ & 45 \\
\hline Halkyn & 23 & $52 \cdot 3$ & $\begin{array}{c}18 \cdot 2 \\
(5 \cdot 7)\end{array}$ & - & $\begin{array}{c}13.7 \\
(6.9)\end{array}$ & 25 \\
\hline Henllan & 21 & 33.6 & - & $\begin{array}{l}8.0 \\
(1.9)\end{array}$ & $\begin{array}{c}7.6 \\
(4.6)\end{array}$ & 5 \\
\hline Halkyn & 104 & $45 \cdot 1$ & - & $\begin{array}{c}12 \cdot 3 \\
(4 \cdot 4)\end{array}$ & $\begin{array}{c}10.2 \\
(3.5)\end{array}$ & 17 \\
\hline
\end{tabular}

Note: 1 Subjects seen in 1981 were all females; those seen in 1976 were of both sexes.

2 Mean difference in blood lead levels of subjects seen in 1976 and $1984=6.5$ SE $0.53(\mathrm{p}<0.001)$ and in those seen in 1981 and $1984=1.9$ SE $0.34(\mathrm{p}<0.001)$. 
original estimates was 14.7 and of the re-estimations in 1984 was $16.5 \mu \mathrm{g} / \mathrm{dl}$, a rise of $17 \%$. These stored samples were the residues of samples which had been used for a number of tests and were consequently of rather small volume (about $1 \mathrm{ml}$ blood or less in a 5 $\mathrm{ml}$ container). We believe that the rise in the estimations is likely to represent to some extent, and probably to a large extent, evaporation of the samples.

As another check on our laboratory, duplicate blood samples taken from a haphazard subsample of subjects were sent to the Southampton Supra-Regional Assay Laboratory (Dr Trevor Delves). This procedure has been followed in almost every survey of blood lead carried out by this unit, and the two laboratories' findings have always been closely comparable. In 1978 duplicate samples from 68 subjects showed that our laboratory was giving results which were $4 \%$ higher than those of the Southampton laboratory. In 1981 our laboratory gave results on 53 samples which were $6 \%$ higher than those of Southampton. On the occasion of the present survey duplicates, again from 53 subjects, showed our laboratory to be about $15 \%$ higher (1.56 SE $0 \cdot 16 \mu \mathrm{g} / \mathrm{dl}$ ). These differences are reassuring as they indicate that comparisons of changes in blood lead over time, based on results from our own laboratory, are likely to underestimate the true fall.

\section{Discussion}

There are many possible reasons for the fall in blood lead levels which we describe. Concern about lead has grown enormously, and it is likely that exposure from many environmental sources has diminished over the past ten years. Lead in food has probably diminished, ${ }^{6}$ and although there were no major works completed in any of the areas we surveyed, lead in water may well have been reduced in most areas.

It is difficult to be certain about changes in lead in air. Lead from car exhausts is the main determinant of airborne lead, and during 1971-82 inclusive the amount of lead added to petrol in the UK (around 11000 tonnes pa) varied by only about $\pm 5 \% .{ }^{67}$ More recent figures are not yet available, and although the concentration of lead in petrol is being reduced (most recently it is $0.37 \mathrm{~g} / 1$ compared to $0.4 \mathrm{~g} / 1$ in 1981 ), sales of petrol were increasing up to $1982^{7}$ and have probably continued to do so.

In any case, all but two of the areas described in this report are rural and remote from major traffic flows, and the changes in blood lead levels in these are similar to the changes in the rather more urban areas, Greenfield and Ruthin. Furthermore, we do have measurements of air lead in two of the areas described in the present report, and these were very close to the limit of detection. In Henllan, in 1981, the mean indoor air lead, measured for seven days in each of nine dwellings, was $0.03 \mu \mathrm{g} / \mathrm{m}^{3}$ and in Halkyn the mean in 12 dwellings was $0.07 \mu \mathrm{g} / \mathrm{m}^{3}{ }^{8}$ In a study of the environmental determinants of blood lead, which included Henllan as one of five selected areas in Wales, together with several major urban areas, air was found to be only a minor determinant. ${ }^{9}$

We are confident therefore that the fall in blood lead level which we described is a consequence of changes in the exposure of subjects to lead in sources other than air, but we have inadequate evidence from which to identify any particular source. Lead in water is unlikely to be relevant: the area has no water plumbosolvency problem, and in 1981 "random daytime" samples were taken in the homes of all the subjects in Halkyn and Henllan, and the geometric mean was found to be only $2 \mu \mathrm{g} / \mathrm{l}$, very close to the limit of detection. Tobacco smoking is at the most a very minor determinant of blood lead in women, ${ }^{10}$ and the available data indicate that smoking among women has changed little in recent years. ${ }^{11}$ We surmise therefore that the most likely cause of the fall in blood lead is a reduction in lead in food and beverages. While we have no data for the populations we describe, the on-going UK Total Diet Study, ${ }^{12}$ which is based on analyses of simulated diets, estimated the intake of an average adult subject to be $111 \mu \mathrm{g} /$ day in $1976,16 \mu \mathrm{g}$ of which was from beverages, while in 1981 the estimate was $80 \mu \mathrm{g} / \mathrm{day}$, $8 \mu \mathrm{g}$ from beverages. Presumably these reductions are due to improved food handling and processing and will have continued to 1984 .

The data we present are not unique and there are a number of other studies which suggest that a fall in blood lead levels has occurred both throughout the UK and in other countries.

The Department of the Environment describe a fall of about 5\% per year between two series of surveys throughout the UK in 1979 and $1981 .{ }^{13}$ Indeed, while the earlier surveys had been based on random samples of defined communities, an attempt was made in 1981 to survey communities in areas of possible lead pollution, and it could therefore be argued that a true fall in blood lead was underestimated in these surveys. A report based on male subjects presenting for pre-employment medical examinations in the UK in 1967-69 and in 1978-80 also suggested a fall, of about $18 \%{ }^{15}$

In the USA, NHANES II showed a $37 \%$ change in the mean blood lead levels of samples of subjects seen in 64 areas during 1976-80. ${ }^{1}$ Further evidence comes from cord blood samples taken in Boston. ${ }^{15}$ These suggest a fall in blood lead of about $11 \%$ per year between 1979 and 1981, and a note in the report 
which describes these data comments that there had been a fall over the previous decade of about $7 \%$ per year.

Finally, a report from New Zealand ${ }^{16}$ describes a fall of about $4 \%$ per year both in unexposed "normal" subjects and in subjects examined in pre-employment examinations between 1974 and 1984. While the subjects of this report are not representative of the general population, the report states that the criteria for selection for testing for lead were unchanged during the period of the report.

All these reports yield estimates of changes in blood lead which are fairly similar to those we report from Wales, namely, about 4 to $5 \%$ per year since about the early $1970 \mathrm{~s}$. While none of the reports comes from studies set up to examine changes over time, and all can therefore be faulted, some conviction is given by the fact that, despite differences in population sampling and in design, the results of these different surveys are remarkably similar. Furthermore, the changes reported from NHANES II, and attributed to a reduction in gasoline lead, are little different from those reported from the UK and New Zealand where no substantial changes in petrol lead levels have yet taken place.

\section{References}

${ }^{1}$ Annest JL, Pirkle JL, Makuc D, Neese JW, Bayes DD, Kovar MG. $N$ Engl J Med 1983; 308: 1373-7.

${ }^{2}$ Elwood PC. Br Med J 1983; 286: 1515.

${ }^{3}$ Elwood PC. Br Med J 1983; 286: 1553.

${ }^{4}$ Thomas HF, Moore F, Welsby E, Elwood PC, Firth JNM. Br J Prev Soc Med 1977; 31: 265-8.

${ }^{5}$ Gallacher JEJ, Elwood PC, Phillips Karin M, Davies BE, Ginnever RC, Toothill C, Jones DT. J Epidemiol Community Health 1984; 38: 173-6.

${ }^{6}$ Royal Commission on Environmental Pollution. Ninth Report. Lead in the environment. London: HMSO, 1983.

${ }^{7}$ Department of Transport. Lead in petrol. An assessment of the feasibility and costs of further action to limit lead emissions from vehicles. London: Department of Transport, 1979.

${ }^{8}$ Plwm Yng Nghymru: Lead in Wales. MRC Epidemiology Unit 1983. ISBN 0950895105.

'Elwood PC, Gallacher JEJ, Phillips Karin M, Davies BE, Toothill C. Nature 1984; 310: 138-40.

${ }^{10}$ Grandjean P, Olsen NB, Hollnagel H. Int Arch Occup Environ Health 1981; 48: 391-7.

${ }^{11}$ Acheson ED. Health Trends 1985; 17: 27-8.

${ }^{12}$ Ministry of Agriculture, Fisheries and Food. Survey of lead in food. Food Surveillance Paper No. 10, 1982. London: HMSO.

${ }^{13}$ Department of the Environment. London: DoE Pollution Report No. 18, 1983.

${ }^{14}$ Oxley GR. Int Arch Occup Environ Health 1982; 341-3.

${ }^{15}$ Rabinowitz MB, Needleman HL. Science 1982; 216:

${ }^{16}$ Malpress WA, Janus ED, Hinton Daphne. NZ Med J 1984; 97: 869 . 